Article

\title{
Taurine Enhances Iron-Related Proteins and Reduces Lipid Peroxidation in Differentiated C2C12 Myotubes
}

\author{
Ulrike Seidel *, Kai Lüersen, Patricia Huebbe and Gerald Rimbach $(\mathbb{D}$ \\ Institute of Human Nutrition and Food Science, University of Kiel, 24118 Kiel, Germany; \\ luersen@foodsci.uni-kiel.de (K.L.); huebbe@foodsci.uni-kiel.de (P.H.); rimbach@foodsci.uni-kiel.de (G.R.) \\ * Correspondence: seidel@foodsci.uni-kiel.de; Tel.: +49-0431-880-5334
}

Received: 26 August 2020; Accepted: 29 October 2020; Published: 31 October 2020

\begin{abstract}
Taurine is a nonproteinogenic amino sulfonic acid in mammals. Interestingly, skeletal muscle is unable to synthesize taurine endogenously, and the processing of muscular taurine changes throughout ageing and under specific pathophysiological conditions, such as muscular dystrophy. Ageing and disease are also associated with altered iron metabolism, especially when there is an excess of labile iron. The present study addresses the question of whether taurine connects cytoprotective effects and redox homeostasis in a previously unknown iron-dependent manner. Using cultured differentiated $\mathrm{C} 2 \mathrm{C} 12$ myotubes, the impact of taurine on markers of lipid peroxidation, redox-sensitive enzymes and iron-related proteins was studied. Significant increases in the heme protein myoglobin and the iron storage protein ferritin were observed in response to taurine treatment. Taurine supplementation reduced lipid peroxidation and BODIPY oxidation by $\sim 60$ and $25 \%$, respectively. Furthermore, the mRNA levels of redox-sensitive heme oxygenase (Hmox1), catalase (Cat) and glutamate-cysteine ligase (Gclc) and the total cellular glutathione content were lower in taurine-supplemented cells than they were in the control cells. We suggest that taurine may inhibit the initiation and propagation of lipid peroxidation by lowering basal levels of cellular stress, perhaps through reduction of the cellular labile iron pool.
\end{abstract}

Keywords: skeletal muscle; labile iron pool; myoglobin; glutathione; BODIPY

\section{Introduction}

Iron plays an important role in physiological and pathophysiological biochemical processes. The pool of iron in the body consists of heme proteins (hemoglobin, myoglobin and heme enzymes), transport and storage proteins (transferrin and ferritin) and functional iron-sulfur cluster proteins (e.g., complexes I, II and III of the respiratory chain) [1,2]. Iron-dependent proteins are important for enabling cellular growth and proliferation $[3,4]$ and energy metabolism $[5,6]$. The majority of cellular iron is bound to proteins, and only a small proportion (1-2\%) is free. The so-called labile iron is chelatable and includes both ferrous $\left(\mathrm{Fe}^{2+}\right)$ and ferric $\left(\mathrm{Fe}^{3+}\right)$ ions [7]. Labile iron acts as a catalyst for the generation of reactive oxygen species (ROS), through, for example, the Fenton reaction $\left(\mathrm{Fe}^{2+}+\mathrm{H}_{2} \mathrm{O}_{2}\right.$ $\left.\rightarrow \mathrm{Fe}^{3+}+\mathrm{OH}^{-}+\mathrm{OH}^{\bullet}\right)$, which forms highly reactive hydroxyl radical $\left(\mathrm{OH}^{\bullet}\right)$ species. Reactive oxygen species such as $\mathrm{OH}^{\bullet}$ promote lipid peroxidation [8] and oxidative damage to other biomolecules.

Taurine is a nonproteinogenic amino sulfonic acid that is either endogenously produced from the degradation of methionine and cysteine $[9,10]$ or is derived from dietary sources of animal origin [11]. For chemical structure see Scheme 1. 
<smiles>NCCS(=O)(=O)O</smiles>

Taurine uncharged<smiles>[NH3+]CCS(=O)(=O)[O-]</smiles>

Taurine zwitterionic

Scheme 1. Chemical structure of taurine showing its two functional groups, the amino group and the sulfonic acid group. Taurine is zwitterionic at an isoelectric point of 5.12 [12]. The molecular weight of taurine is $125.15 \mathrm{~g} / \mathrm{mol}$ and the molecular formula is C2H7NO3S [13].

Excitatory tissues such as the retina, brain, heart and skeletal muscle $[12,14,15]$ contain especially high concentrations of taurine. These tissues have a high metabolic rate and are highly vulnerable to oxidative damage. Moreover, aging might alter taurine homeostasis in several tissues of laboratory rodents, as shown in Table 1.

Table 1. Relative changes (\%) in tissue taurine/taurine metabolite concentrations in aged compared to young control laboratory rodents.

\begin{tabular}{|c|c|c|c|c|}
\hline Animals & Tissue & $\begin{array}{c}\text { Taurine/Taurine } \\
\text { Metabolites }\end{array}$ & $\begin{array}{l}\text { Relative Changes in } \\
\text { Aged Compared to Young } \\
\text { Control Animals }\end{array}$ & Reference \\
\hline C57 BL/6J mice & Lens & $\begin{array}{l}\text { Hypotaurine, } \\
\text { cystathionine }\end{array}$ & $>70 \%$ decrease & [16] \\
\hline & $\begin{array}{c}\text { Skeletal muscle } \\
\text { (Rectus femoris) } \\
\text { Heart muscle }\end{array}$ & & $\begin{array}{l}\sim 15 \% \text { decrease } \\
\sim 55 \% \text { increase }\end{array}$ & \\
\hline C57 BL/6J mice & $\begin{array}{l}\text { Brain } \\
\text { Liver } \\
\text { Kidney } \\
\text { Blood }\end{array}$ & Taurine & $\begin{array}{l}\sim 35 \% \text { decrease } \\
\text { No change } \\
\text { No change } \\
\text { No change }\end{array}$ & [17] \\
\hline Long-Evans rats & $\begin{array}{c}\text { Brain (Striatum) } \\
\text { Liver }\end{array}$ & Taurine & $\begin{array}{l}\sim 20 \% \text { decrease } \\
\sim 60 \% \text { decrease }\end{array}$ & [18] \\
\hline Fischer 344 rats & $\begin{array}{c}\text { Kidney } \\
\text { Brain (Cerebellum) }\end{array}$ & Taurine & $\begin{array}{l}\sim 30 \% \text { decrease } \\
\sim 14 \% \text { decrease }\end{array}$ & [19] \\
\hline Wistar rats & $\begin{array}{l}\text { Skeletal muscle } \\
\text { (Tibialis anterior) } \\
\text { Blood }\end{array}$ & Taurine & $\begin{array}{c}\sim 25 \% \text { decrease } \\
\text { No change }\end{array}$ & [20] \\
\hline
\end{tabular}

Skeletal muscle is the main storage site for taurine in the mammalian body. Interestingly, in humans [21] and other species [22-25], taurine was shown to be substantially higher in oxidative type I compared to glycolytic type II muscles. Muscle senescence and atrophy are accompanied by declining cellular taurine concentrations [20,26,27], altered iron metabolism and increased oxidative injury [28,29]. Furthermore, ageing and disease are also associated with altered iron metabolism, especially when there is an excess of labile iron. Therefore, a causal relationship between taurine and iron metabolism in muscle health and disease is plausible. Research in recent decades has revealed that taurine exhibits cytoprotective properties and prevents tissues from oxidative injury [10]. Potential molecular mechanisms of taurine, such as free-radical scavenging activity [15,30], induction of antioxidative defense mechanisms [31-33] and diminished generation of reactive oxygen species (ROS) [34], have been proposed. Moreover, in iron-overload rodent models, dietary taurine reduced myocardial [35] and hepatic [36,37] tissue injury caused by oxidative stress. The induction of antioxidative defense mechanisms, such as higher activity of antioxidative enzymes or elevated glutathione levels, was suggested to underlie the cytoprotective properties of taurine [35,36]. Apart from that, little is known about the potential direct effects taurine may exert on catalytic transition metals such as iron. One possibility that has been discussed by Petrova and Neudachina is that taurine may have the ability to physically bind metal ions [38]. However, experimental evidence of the physical 
interaction between taurine and iron has not yet been provided. Muscle cells are particularly suitable for studying the molecular effects of taurine due to the lack of key enzymes required for endogenous taurine synthesis. In the present study, differentiated C2C12 mouse myoblasts were used to examine the molecular effects of taurine on cellular iron and redox homeostasis.

\section{Materials and Methods}

\subsection{Cell Culture}

C2C12 cells were purchased from IAZ (Institute for applied cell culture, Munich, Germany). Myoblasts were maintained in Dulbecco's modified Eagle's medium (DMEM, high glucose $4.5 \mathrm{~g} / \mathrm{L}$, P04-03590, PAN ${ }^{\mathrm{TM}}$ Biotech $\mathrm{GmbH}$ ) supplemented with 20\% (v/v) fetal bovine serum (FBS) and 1\% Pen/Strep. Final experiments were conducted with differentiated myotubes. To this end, cells were seeded into cell culture plates and proliferated until they reached approximately $90 \%$ confluence ( $\sim 48 \mathrm{~h}$ later). Myogenesis was initiated by switching the growth medium ( $20 \% \mathrm{FBS})$ to differentiation medium containing $2 \%$ horse serum. The differentiation medium was refreshed every $24 \mathrm{~h}$. After four days of differentiation cells expressed the intended morphology of fused myotubes. At day four the differentiation medium was supplemented with taurine or respective other substances. If not indicated otherwise, the abbreviation TAUR means that cells were treated with $5 \mathrm{mmol} / \mathrm{L}$ taurine in differentiation medium.

\subsection{Cell Viability Test}

Cell viability was estimated via neutral red uptake assay [39]. Cells were seeded in 24-well plates and were differentiated as described in the "Cell culture" section. C2C12 myotubes were incubated with taurine (Sigma Aldrich, T0625, Darmstadt, Germany) in a range of concentrations (1-250 mmol/L) and $10 \%$ ethanol as the positive control to induce cytotoxicity. After $24 \mathrm{~h}$, the cells were incubated with $1 \%$ neutral red solution (Carl Roth $\mathrm{GmbH}$, Karlsruhe, Germany) for $2 \mathrm{~h}$. Afterwards, cells were lysed in a discoloration solution, and adsorption of neutral red was measured with a microtiter plate reader at $540 \mathrm{~nm}$ (iEMS Reader MF, MTX Labsystem Inc.,Vienna USA).

\subsection{Thiobarbituric Acid Reactive Substances (TBARS)}

Lipid peroxidation was determined by colorimetric TBARS assays according to the method described by Kai (1978) [40]. Differentiated myotubes were cultured in 6-well plates and treated with $5 \mathrm{mmol} / \mathrm{L}$ taurine, $250 \mu \mathrm{M}$ Trolox or control medium for $48 \mathrm{~h}$. Fresh treatments replaced the old after $24 \mathrm{~h}$. Cells were harvested by scraping with Dulbecco's phosphate-buffer saline (DBPS) on ice. Total protein content was estimated using the bicinchoninic acid (BCA) method (Pierce ${ }^{\mathrm{TM}}$ BCA Protein Assay, Thermo Scientific, Waltham, USA). Proteins of the remaining cell suspension were precipitated with $5 \%$ trichloroacetic acid (TCA). The supernatant $(200 \mu \mathrm{L})$ was stabilized in $20 \mu \mathrm{L}$ of $0.5 \%$ mixture of sodium docecyl sulfate (SDS)-butylated hydroxytoluene (BHT), and an equivalent volume of $1 \%$ thiobarbituric acid (TBA) was added. The mixture was incubated for $20 \mathrm{~min}$ at $99{ }^{\circ} \mathrm{C}$. After cooling on ice, $1 \mathrm{~mL}$ of butanol was added to the mixture to extract the pink trimetin colorant. The supernatant was transferred to a 96-well plate in triplicate. Fluorescence $(\lambda e x=520 \mathrm{~nm} / \lambda \mathrm{em}=560 \mathrm{~nm})$ was measured with a microplate reader. Tetraethoxypropane (Sigma Aldrich, Darmstadt, Germany) was used as an external standard. 


\subsection{Lipid Peroxidation Determined by BODIPY Assay}

C11-BODIPY (581/591) (Life Technologies, D-3861, Darmstadt, Germany) is a fluorescent dye that can be used as a lipid peroxidation sensor. This fatty acid analogue is lipophilic and incorporates into biomembranes. After being oxidized, the fluorescent properties of C11-BODIPY shift due to the change from the reduced $\left(\lambda_{\mathrm{ex}}=540 \mathrm{~nm} / \lambda_{\mathrm{em}}=595 \mathrm{~nm}\right)$ to the oxidized $\left(\lambda_{\mathrm{ex}}=480 \mathrm{~nm} / \lambda_{\mathrm{em}}=520 \mathrm{~nm}\right)$ state. The adjusted index of BODIPY oxidation was calculated as follows:

$$
\text { Adjusted Index }=\mathrm{Em}_{\mathrm{Ox}} /\left(\mathrm{Em}_{\mathrm{Ox}}+\mathrm{Em}_{\mathrm{Red}}\right)
$$

C2C12 cells were seeded in black-walled, clear-bottom 96-well cell culture plates. C2C12 cells were first differentiated as described previously. Prior to the addition of BODIPY, cells were incubated with medium (CON) or taurine (TAUR). After $24 \mathrm{~h}$, the medium was removed, and the cells were rinsed and treated with $10 \mu \mathrm{M}$ BODIPY in medium for $30 \mathrm{~min}$. Then, the medium was removed, and the cells were exposed to either $2 \mu \mathrm{mol} / \mathrm{L}$ iron(II) sulfate ( $\mathrm{Fe}^{2+}$, Merck, Germany), $80 \mu \mathrm{mol} / \mathrm{L}$ cumene hydroperoxide (CumOOH, Sigma Aldrich, Germany) or a mixture of $2 \mu \mathrm{mol} / \mathrm{L} \mathrm{Fe}^{2+}$ and $80 \mu \mathrm{mol} / \mathrm{L}$ CumOOH in DPBS at $37^{\circ} \mathrm{C}$ for $1 \mathrm{~h}$. Afterwards, cells were washed with DBPS, and fluorescence of adherent cells was measured using a microplate reader (TECAN infinite F200, Grödig, Austria).

\subsection{Cellular Total Glutathione}

Cells were treated without $(\mathrm{CON})$ or with $5 \mathrm{mmol} / \mathrm{L}$ taurine (TAUR) for $24 \mathrm{~h}$. After the medium was removed, adherent cells were washed with DPBS and lysed in $10 \mathrm{mM} \mathrm{HCl}$ by being subjected to freeze-thaw cycles. The total protein content in the lysates was determined by the BCA method. The remaining lysates were used for GSH detection after proteins were precipitated with an equal volume of $6.5 \%$ sulfo salicylic acid (SSA). The GSH concentration was measured according to the enzymatic recycling method described by [41,42]. In short, GSH is oxidized by $5,5^{\prime}$-dithio-bis(2-nitrobenzoic acid) (DTNB) to form glutathione disulphide (GSSG) and 5'-thio-2-nitrobenzoic acid (TNB). The latter can be measured at $412 \mathrm{~nm}$. In the presence of nicotinamide adenine dinucleotide phosphate (NADPH), GSSG can be recycled by GSH reductase. Here, $20 \mu \mathrm{L}$ of standards/samples were transferred to a 96-well plate and incubated for $5 \mathrm{~min}$ with $200 \mu \mathrm{L}$ of reagent $\operatorname{mix}(1 \mathrm{mmol} / \mathrm{L}$ DTNB and $0.34 \mathrm{mmol} / \mathrm{L} \mathrm{NADPH}$ in stock buffer). Then, $40 \mu \mathrm{L}$ of GSH-reductase $(8.5 \mathrm{IU} / \mathrm{mL})$ was quickly added to each well, and adsorption was measured kinetically every $20 \mathrm{~s}$ for $2 \mathrm{~min}$ at $415 \mathrm{~nm}$ (iEMS Reader MF, MTX Labsystem Inc., Vienna, USA).

\subsection{Quantitative Real Time Polymerase Chain Reaction ( $q R T-P C R$ )}

Differentiated myotubes were incubated in control media in the absence of taurine $(\mathrm{CON})$ or with $5 \mathrm{mmol} / \mathrm{L}$ taurine (TAUR) for $6 \mathrm{~h}$. Afterwards, cells were harvested with peqGOLD TriFast (VWR International $\mathrm{GmbH}$, Darmstadt, Germany), and RNA was isolated according to the manufacturer's instructions. Sample RNA concentrations and quality were assessed with a Nano Drop 2000 UV-Vis spectrophotometer (Thermo Fisher Scientific GmbH, Life Technologies ${ }^{\mathrm{TM}}$, Darmstadt, Germany). Gene expression was analyzed via qRT-PCR with a SensiFAST ${ }^{\mathrm{TM}}$ SYBR $^{\circledR}$ No-ROX One-Step Kit (Bioline $\mathrm{GmbH}$, Luckenwalde, Germany) using a Rotorgene 6000 cycler (Corbett Life Science, Sydney, Australia). The primer sequences used for the quantification of the target genes are listed in Table 2. Relative mRNA levels were quantified as the ratio between the target gene and a housekeeping gene (Ap3d1). 
Table 2. Nucleotide sequences of primers used for quantitative real-time PCR. Primer pairs are listed as forward $(\mathrm{F})$ and reverse $(\mathrm{R})$ with the corresponding annealing temperature (Ta) that was determined individually for all pairs.

\begin{tabular}{|c|c|c|c|c|}
\hline Gene ID & Symbol & Ta $\left({ }^{\circ} \mathrm{C}\right)$ & & Sequence $\left(5^{\prime}-3^{\prime}\right)$ \\
\hline \multirow{2}{*}{55,991} & \multirow{2}{*}{$A p 3 d 1$} & \multirow{2}{*}{55} & $\mathrm{~F}$ & AGGAGCTGAAGCAGGACAAC \\
\hline & & & $\mathrm{R}$ & CGCTTGAATGTGAACTTGGA \\
\hline \multirow{2}{*}{78,653} & \multirow{2}{*}{ Bola3 } & \multirow[b]{2}{*}{61} & $\mathrm{~F}$ & ACCTTGCAGATGTGTCCAGG \\
\hline & & & $\mathrm{R}$ & CTAGAGCAGCATCCCAGAGC \\
\hline \multirow{2}{*}{12,359} & \multirow{2}{*}{ Cat } & \multirow[b]{2}{*}{60} & $\mathrm{~F}$ & CGAGGGTCACGAACTGTGTCA \\
\hline & & & $\mathrm{R}$ & GGTCACCCACGATATCACCAGATAC \\
\hline \multirow{2}{*}{14,319} & \multirow{2}{*}{ Fth } & \multirow{2}{*}{57} & $\mathrm{~F}$ & GTGGCTCTGAAGAACTTTGC \\
\hline & & & $\mathrm{R}$ & AGTCATCACGGTCTGGTTTC \\
\hline \multirow{2}{*}{14,325} & \multirow{2}{*}{ Ftl } & \multirow{2}{*}{57} & $\mathrm{~F}$ & CTTCCAGGATGTGCAGAAG \\
\hline & & & $\mathrm{R}$ & ATCCAAGAGGGCCTGATT \\
\hline \multirow{2}{*}{14,629} & \multirow{2}{*}{ Gclc } & \multirow{2}{*}{57} & $\mathrm{~F}$ & GTGGAGGCCAATATGAGGAA \\
\hline & & & $\mathrm{R}$ & GGGTGCTTGTTTATGGCTTC \\
\hline \multirow{2}{*}{73,046} & \multirow{2}{*}{ Glxr5 } & \multirow{2}{*}{60} & $\mathrm{~F}$ & GACTATGCGGCCTACAACGT \\
\hline & & & $\mathrm{R}$ & GTTGAGGTACACTTGCGGGA \\
\hline \multirow{2}{*}{15,368} & \multirow{2}{*}{ Hmox1 } & \multirow{2}{*}{60} & $\mathrm{~F}$ & GAGCCTGAATCGAGCAGAAC \\
\hline & & & $\mathrm{R}$ & AGCCTTCTCTGGACACCTGA \\
\hline \multirow{2}{*}{56,748} & \multirow{2}{*}{ Nfu1 } & \multirow{2}{*}{60} & $\mathrm{~F}$ & AAGCGTCTTCTTCGGACCAG \\
\hline & & & $\mathrm{R}$ & СTCCTGCACAGTTGGCCTTA \\
\hline \multirow{2}{*}{76,826} & \multirow{2}{*}{ Nubpl } & \multirow{2}{*}{60} & $\mathrm{~F}$ & TGTCTCCACACCTCAGGACA \\
\hline & & & $\mathrm{R}$ & TCTTGCACCATCAGCACCAA \\
\hline \multirow{2}{*}{22,042} & \multirow{2}{*}{ Tfr } & \multirow{2}{*}{57} & $\mathrm{~F}$ & AAGCCAGATCAGCATTCTCT \\
\hline & & & $\mathrm{R}$ & CGGCATTTTCTTCTTCATCT \\
\hline \multirow{2}{*}{21,366} & TauT & 55 & $\mathrm{~F}$ & CGCTCTGCCTCCTCTTAGTC \\
\hline & laut & 50 & $\mathrm{R}$ & GAATTTGATGCCTTCACCAG \\
\hline
\end{tabular}

Ap3d1, Adaptor-related protein complex 3, delta 1 subunit; Bola3, BolA Family Member 3; Cat, Catalase; Fth, Ferritin heavy chain; Ftl, Ferritin light chain; Gclc, Glutamate-cysteine ligase (catalytic subunit); Glxr5, Glutaredoxin; Hmox1, Heme oxygenase 1; Nfu1, Iron-Sulfur Cluster Scaffold; Nubpl, Nucleotide Binding Protein Like; Taut, taurine transporter; Tfr, transferrin receptor.

\subsection{Western Blotting}

Cultivated $\mathrm{C} 2 \mathrm{C} 12$ cells were differentiated and treated with CON or TAUR for $24 \mathrm{~h}$. Cells were harvested on ice with a RIPA-PIC-PhosSTOP (100:1:10) buffer mixture. After cell lysis and centrifugation of the sample, the supernatants quantified via the BCA method and were then subjected to western blotting. For western blotting, $30 \mu \mathrm{g}$ of each sample was loaded on MINI PROTEAN ${ }^{\circledR}$ TGX-Stain-Free ${ }^{\mathrm{TM}}$ precast gels (BioRad, Munich, Germany) and then was separated via gel electrophoresis. Afterward, the proteins were transferred to a membrane (Immuno-Blot ${ }^{\circledR}$ PVDF Membrane for Protein Blotting, BioRad, Munich, Germany), blocked with skimmed milk and incubated with primary antibodies overnight. The following antibodies were used: cytochrome c, $15 \mathrm{kDa}$ (sc-13560, Santa Cruz Biotechnology, Dallas, USA), ferritin heavy chain $21 \mathrm{kDa}$ (sc-376594, Santa Cruz Biotechnology), ferritin light chain, $19 \mathrm{kDa}$ (ab69090, Abcam, Berlin, Germany), myoglobin, 17 kDa (D2F5X, Cell Signaling, Leiden, Netherlands), taurine transporter 65-70 kDa (AB5414P, Merck, Darmstadt, Germany) and total OXPHOS antibody cocktail (ab110413, Abcam). For the taurine transporter, the target band was detected at approximately $140 \mathrm{kDa}$, indicating a dimeric structure. Afterwards, membranes were incubated with a secondary antibody for 1 hour, and bands were visualized using an enhanced chemiluminescence (ECL) substrate and a ChemiDoc XRS system (both BioRad). The signal of targeted bands was densitometrically analyzed and normalized against the total protein load. Image Lab Software 5.2.1 (BioRad, Munich, Germany) was used for protein quantification. 


\subsection{Catalase Activity}

The catalase activity was determined according to Johansson and Borg (1988) [43]. The assay is based on the catalase driven oxidation of methanol in the presence of hydrogen peroxide to produce formaldehyde. Formaldehyde reacts with 4-amino-3-hydrazino-5-mercapto-1,2,4-triazole (Purpald, Sigma Aldrich, Darmstadt, Germany). After addition of alkaline potassium periodate solution, the formaldehyde-purpald adduct oxidizes and develops a color that is detected spectrophotometrically at $540 \mathrm{~nm}$.

For cell culture experiments differentiated myotubes were incubated in 6-well plates with CON and TAUR. After $24 \mathrm{~h}$, cells were sonicated in $200 \mu \mathrm{L}$ of phosphate buffer and supernatant was used for the determination of catalase activity and total protein quantification via BCA method. For the present study, $30 \mu \mathrm{L}$ samples and $66 \mu \mathrm{L}$ assay mix (phosphate buffer, methanol, hydrogen peroxide) were incubated at room temperature for $20 \mathrm{~min}$ before the addition of potassium periodate. The catalase activity was calculated using a dilution series produced by purified catalase from bovine liver (Sigma Aldrich, Darmstadt, Germany).

\subsection{Statistical Analysis}

Statistical analyses were conducted using GraphPad PRISM software (San Diego, CA, USA) and IBM SPSS Statistics 24 (Ehningen, Germany). For statistical hypothesis tests, groups were analyzed for normality of the distribution (Kolmogorov-Smirnov and Shapiro-Wilk tests). In the case of normally distributed data, Levene's test was conducted to assess the homogeneity of variances. If the null hypothesis was rejected (Levene's test indicated it was not significant), for multiple comparison a one-way analysis of variance (ANOVA) with a one-sided Tukey test as post hoc analysis was performed. If the null hypothesis was confirmed (Levene's test indicated significance), the Games-Howell post hoc test was used. For comparison of two groups a $t$-test was performed with normal distributed data while the Mann-Whitney U test was chosen if data did not pass the test of normal distribution.

\section{Results}

\subsection{The Impact of Taurine on Cell Viability and Cellular Taurine Management}

The cell viability of medium control (CON) cells was set as $100 \%$. Taurine tended to be cytotoxic at concentrations $\geq 250 \mathrm{mmol} / \mathrm{L}$ (Figure 1a). Lower taurine concentrations $(5-50 \mathrm{mmol} / \mathrm{L}$ ) increased the absorbance of viable at $540 \mathrm{~nm}$ up to 160\% compared to control. Microscopy images (Figure 1c) illustrate the morphology of already differentiated myotubes after incubation with $10 \%$ ethanol (EtOH) and different taurine concentrations. The control cells exhibited the typical morphology of long myotubes that were formed during four days myogenesis by fusion of $\mathrm{C} 2 \mathrm{C} 12$ myoblast. The treatment with 5 and $100 \mathrm{mmol} / \mathrm{L}$ taurine did not affect cell morphology compared to control cells. The positive cytotoxicity control $\mathrm{EtOH}$ as well as the highest concentration of $250 \mathrm{mmol} / \mathrm{L}$ taurine seemed to reverse the differentiation status of the myotubes which is reflected by cell fragmentation. Moreover, EtOH induced the removal the adherent cells from the plate and their agglomeration within the medium. The lowest taurine concentration that enhanced the cell viability $(5 \mathrm{mmol} / \mathrm{L})$ was used for further experiments and is abbreviated hereafter as TAUR. Furthermore, the mRNA levels of the gene encoding the taurine transporter (Taut) were significantly downregulated, while the TAUT protein levels were not affected by taurine treatment (Figure 1b, Figure S1a). 
(a)

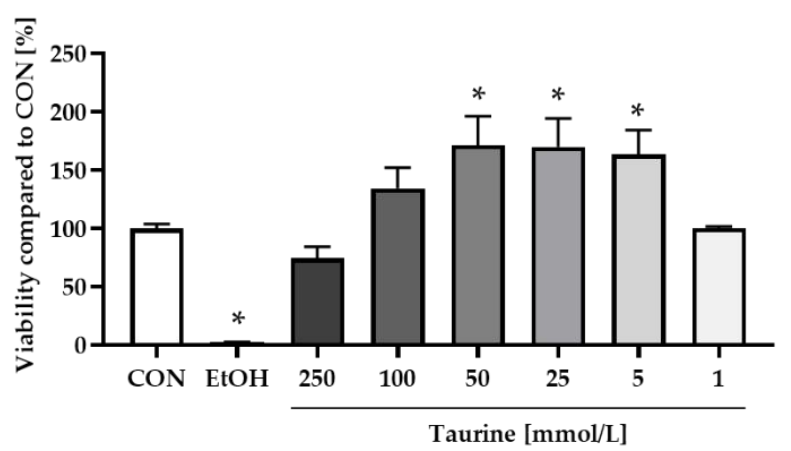

(c)

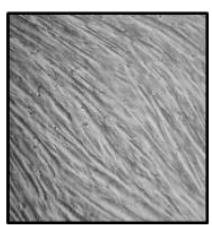

CON

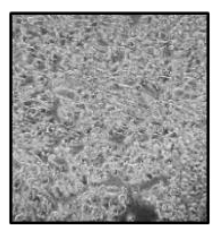

EtOH

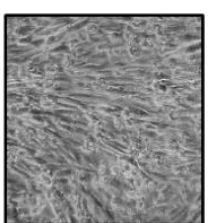

250 (b)
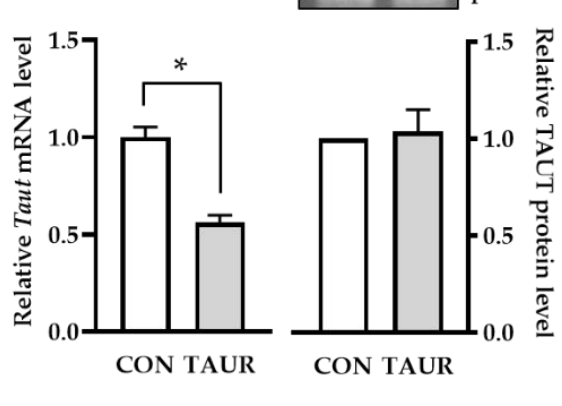

TAUT_140 kDa Representative protein load

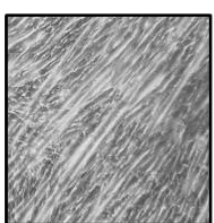

100

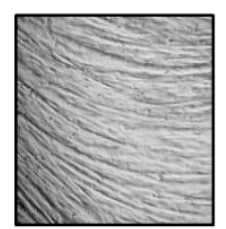

5

Taurine $[\mathrm{mmol} / \mathrm{L}]$

Figure 1. Taurine (TAUR) was not cytotoxic at concentrations of up to $100 \mathrm{mmol} / \mathrm{L}$ (a) Cell viability after $24 \mathrm{~h}$ was determined by the uptake of neutral red by taurine-supplemented $(1-250 \mathrm{mmol} / \mathrm{L})$ myotubes and untreated control (CON) myotubes. Ethanol (10\%) was used as the positive control to induce cytotoxicity. The data are shown as the means + SEM $(n=6-9)$. (b) Compared to CON, TAUR decreased the mRNA levels of the taurine transporter (TAUT), but TAUT protein levels remained unchanged. TAUT protein levels were quantified densitometrically and normalized according to total protein per lane. A representative section of the target bands and corresponding total protein bands visualized by UV are shown. (c) Optical microscopy images $(200 \times)$ of differentiated myotubes show morphological changes and cell fragmentation induced by treatment with $\mathrm{EtOH}$ and the highest taurine concentration $(250 \mathrm{mmol} / \mathrm{L})$, whereas cells incubated with $5 \mathrm{mmol} / \mathrm{L}$ taurine did not differ from CON cells. The data are shown as the means $+\operatorname{SEM}(n=3$ for taurine and TAUT analysis; $n=6$ for Taut mRNA experiments). ${ }^{*}$ Indicates significant differences compared to CON; $p<0.05$.

\subsection{The Impact of Taurine on Celluar Redox-Homeostasis}

Cellular lipid peroxidation (LPO) was determined using TBARS and BODIPY assays (Figure 2a,b). Under basal conditions, taurine significantly prevented the generation of secondary LPO products (TBARS) by approximately $60 \%$ within $48 \mathrm{~h}$. For the BODIPY assay, CON-and TAUR-pretreated cells were loaded with the fluorescent dye C11 BODIPY (581/591), a fatty acid analogue that incorporates into the cell membrane. BODIPY oxidation was measured under basal conditions (without any exogenous stressors) and after $60 \mathrm{~min}$ of supplementation with iron $\left(\mathrm{Fe}^{2+}\right)$ and cumene hydroperoxide (CumOOH). In general, $\mathrm{Fe}^{2+}$ itself did not affect BODIPY oxidation, while BODIPY oxidation was induced by CumOOH. Taurine significantly counteracted CumOOH-induced BODIPY oxidation $(-25 \%)$. In addition, the mRNA levels of genes encoding redox-sensitive enzymes were quantified in control and taurine-treated cells. The mRNA levels of heme oxygenase 1 (Hmox1), catalase (Cat) and glutamate-cysteine ligase catalytic subunit $(\mathrm{Gclc})$ were downregulated in response to taurine treatment (Figure 2c). In line with the decline of the Cat mRNA level, the catalase activity was significantly lower in taurine-treated compared to control cells. In addition, the reduced Gclc mRNA level detected in taurine-treated cells, was accompanied by an approximately $50 \%$ drop of the total cellular glutathione level, which consists of reduced (GSH) and oxidized (GSSG) glutathione (Figure 2d). 
(a)

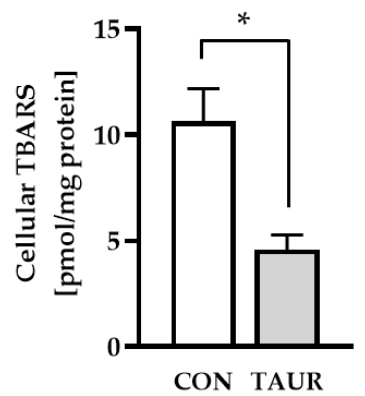

(c)

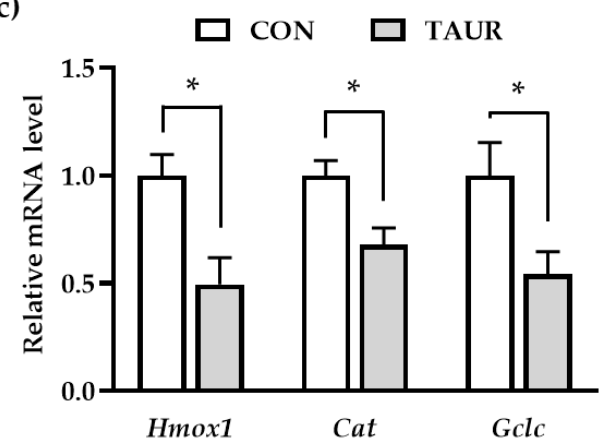

(b)

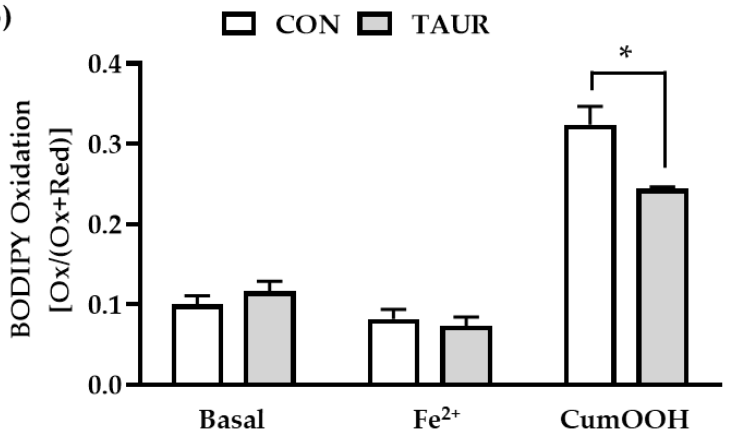

(d)

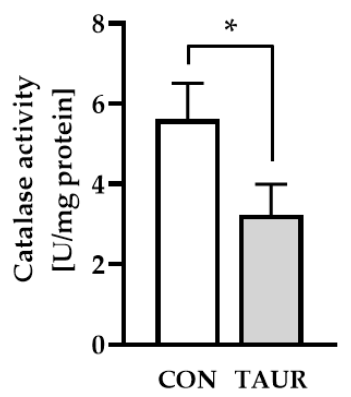

(e)

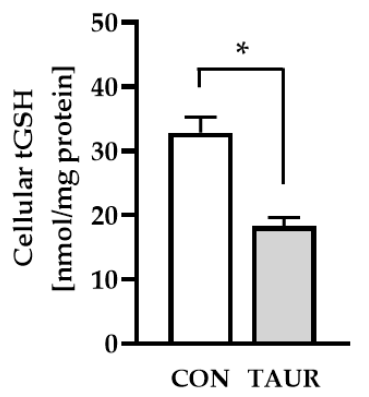

Figure 2. Taurine (TAUR) reduced markers for lipid peroxidation (LPO) and cellular redox homeostasis. (a) TAUR reduced the level of secondary LPO products measured as thiobarbituric acid reactive substances (TBARS). (b) To examine LPO under basal and stress conditions, myotubes were treated with the fluorescent dye C11 (undecanoic acid)-BODIPY 581/591, and then DPBS buffer was added in the absence or presence of $2 \mu \mathrm{mol} / \mathrm{L}$ iron(II) sulfate $\left(\mathrm{Fe}^{2+}\right)$ and $80 \mu \mathrm{mol} / \mathrm{L}$ cumene hydroperoxide (CumOOH). TAUR counteracted CumOOH-induced lipid peroxidation. BODIPY oxidation was determined by the ratio of oxidized to total BODIPY (oxidized + reduced) measured as fluorescence intensity. (c) The mRNA levels of heme oxygenase 1 (Hmox1), catalase (Cat) and glutamate-cysteine ligase, catalytic subunit (Gclc) were downregulated after $6 \mathrm{~h}$ of treatment with TAUR. (d) Catalase activity was significantly downregulated due to $24 \mathrm{~h}$ of incubation with TAUR compared to CON. (e) TAUR decreased the cellular content of total glutathione (tGSH = GSH + GSSG) under basal conditions. The data are shown as the means $+\operatorname{SEM}(n \geq 6)$. ${ }^{*}$ Indicates significant differences compared with $\mathrm{CON} ; p<0.05$. Glutathione (GSH); glutathione disulfide (GSSG).

\subsection{The Impact of Taurine on Iron-Related Proteins}

The protein levels of four iron-related proteins were analyzed via western blotting (Figure 3a, Figure S1b-e). The light chain ferritin isoform (FTL), which is involved in cellular iron storage, increased more than two-fold in response to taurine treatment. However, the heavy chain ferritin isoform (FTH) was not affected by taurine supplementation. The protein levels of the heme protein CYTC were slightly increased, and compared to the control, the MB protein amount was 1.7 times higher upon taurine incubation. The relative mRNA levels of Ftl, Fth and Tfr were analyzed, since their expression is tightly regulated by intracellular iron availability (Figure 3b). As a positive control, $\mathrm{C} 2 \mathrm{C} 12$ cells were treated with $2 \mu \mathrm{mol} / \mathrm{L} \mathrm{Fe}^{2+}$-sulfate. Iron-treated myotubes exhibited significantly higher Ftl mRNA expression, while Tfr mRNA expression was downregulated. Taurine did not affect Ftl, Fth or Tfr mRNA levels compared to those of the control. Furthermore, protein levels of specific subunits representing the presence of mitochondrial oxidative phosphorylation complexes were not affected by the taurine treatment (Figure 3c, Figure S1f). In addition, the mRNA levels of four genes encoding proteins that are involved in iron-sulfur-cluster (ISC) protein synthesis and assembly were quantified via qRT-PCR. Taurine supplementation led to a 1.5-fold increase in mRNA levels of the 
Nubpl gene. The mRNA levels of genes encoding for Nfu1, Bola3 and Glxr5 did not differ between control and taurine treated cells (Figure 3d).
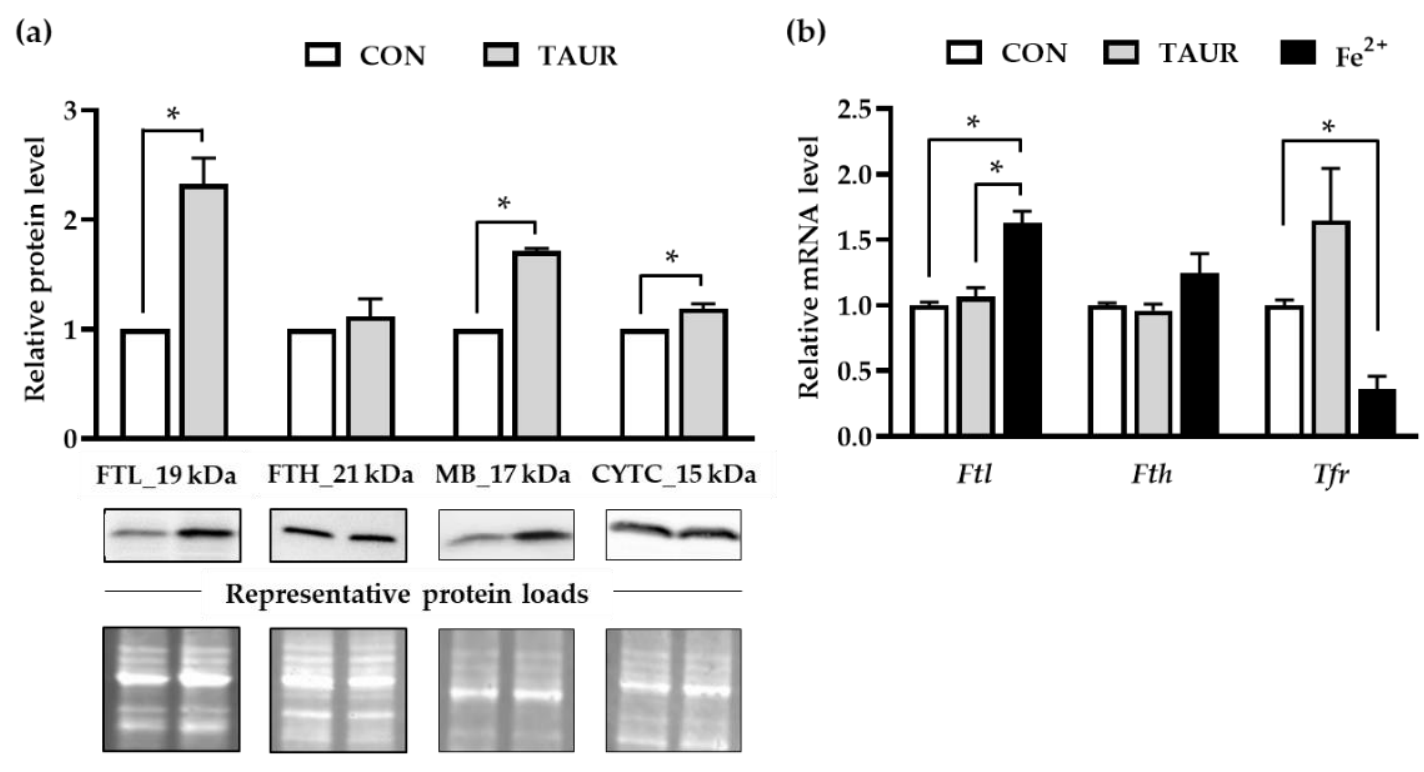

(c)

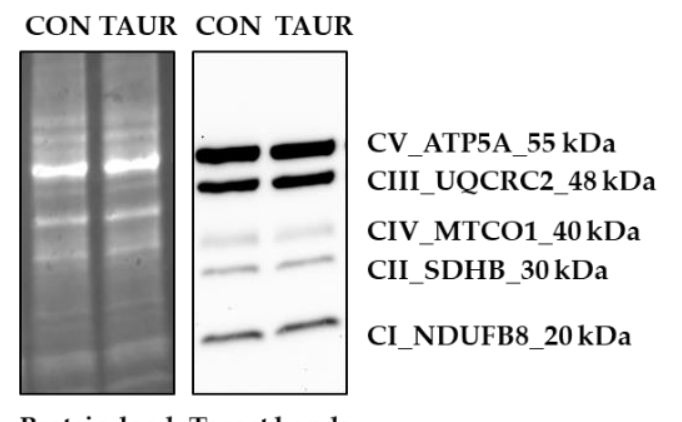

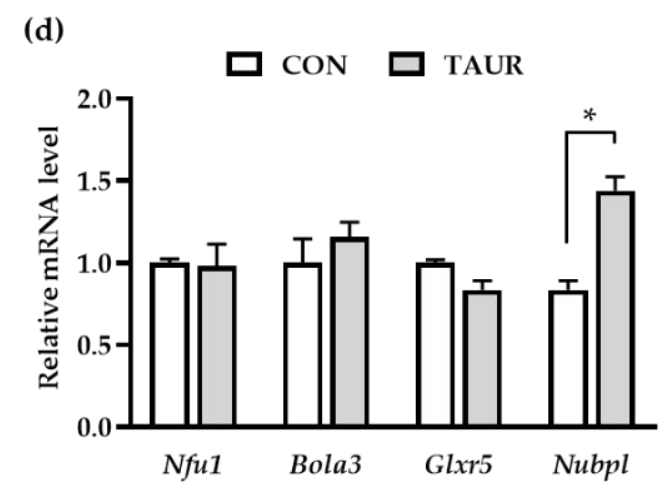

Figure 3. Taurine enhanced ferritin and myoglobin protein levels. (a) The mean protein levels of ferritin light chain (FTL), cytochrome c (CYTC) and myoglobin (MB) were increased after taurine (TAUR) supplementation. The levels in the untreated control (CON) were set to 1 for each individual experiment, and the results of TAUR supplementation are given relative to those of CON. Target band intensity was densitometrically analyzed and normalized by total protein load per lane, as visualized in a stain-free UV image. Representative pictures of the target bands (FTL, FTH, CYTC and $\mathrm{MB}$ ) and the corresponding total protein bands are shown. (b) The mRNA levels of iron-sensitive genes Ftl, Fth and Tfr were quantified in response to treatment with TAUR and iron (II) sulfate $\left(\mathrm{Fe}^{2+}\right)$. $\mathrm{Fe}^{2+}$, which was used as a positive control, significantly enhanced $\mathrm{Ftl}$ and decreased Tfr mRNA levels compared to those of untreated cells. The mRNA levels of Fth were not affected by $\mathrm{Fe}^{2+}$ or taurine. (c) A representative picture of target bands indicating the subunits of mitochondrial oxidative phosphorylation (OXPHOS) complexes CI (NADH dehydrogenese), CII (succinate dehydrogenase), CIII (ubiquinol-cytochrome c reductase), CIV (cytochrome c oxidase) and CV (ATP-Synthase) for CON and TAUR and the corresponding total protein load are shown. (d) The relative mRNA levels of NFU1 iron-sulfur cluster scaffold (Nfu1), BolA FAMILY MEMBER 3 (Bola3) and glutaredoxin 5 (Glxr5) were not affected, while nucleotide binding protein like (Nubpl) mRNA was upregulated in response to taurine supplementation. The data are shown as the means $+\mathrm{SD}(n=3)$ for the protein analysis and means $+\operatorname{SEM}(n=6)$ for mRNA results. ${ }^{*}$ Indicates a significant difference; $p<0.05$. 


\section{Discussion}

Differentiated C2C12 mouse myotubes were used as a cell culture model to study the impact of taurine on cellular redox homeostasis and iron metabolism. Since skeletal muscle is not able to synthesize appropriate amounts of taurine, muscle cells need to take up circulating taurine via active transport to prevent deficiency symptoms such as impaired muscle function and energy metabolism $[44,45]$. In the present study, cultured myotubes were supplied with exogenous taurine via cell culture medium. Therefore, an appropriate, non-toxic concentration of taurine was initially established by the neutral red assay. The highest taurine concentration $(250 \mathrm{mmol} / \mathrm{L})$ significantly reduced the viability of $\mathrm{C} 2 \mathrm{C} 12$ myotubes. Interestingly, taurine concentrations between 5 and $100 \mathrm{mmol} / \mathrm{L}$ seemed to enhance the cell viability compared to control. The neutral red assay provides information on the number of living cells which were calculated relative to the amount of living control cells. Since control cells were not exposed to external stress, we suggest that taurine did not prevent the degradation of existing myotubes but rather re-activates the proliferation of quiescent myoblasts. However, this point needs further investigation.

Physiological taurine concentrations have already been determined to be approximately 15 to $30 \mathrm{mmol} / \mathrm{L}$ in mouse skeletal muscle [46-48]. However, there is a substantial concentration gradient between intracellular and extracellular mammalian taurine levels in vivo [12,49]. To attain more physiological extracellular taurine levels, $5 \mathrm{mmol} / \mathrm{L}$ taurine was used for further experiments. In vivo, transcellular taurine transport occurs actively against a concentration gradient [12]. The taurine transporter (TAUT) is encoded by the solute carrier family 6 member 6 (Slc6a6; Taut) gene. In our study, Taut mRNA was significantly downregulated (by 50\%) in response to supplementation of the cell culture medium with $5 \mathrm{mmol} / \mathrm{L}$ taurine. Accordingly, Han et al. reported on a concentration and time dependent downregulation of Taut mRNA at physiological extracellular taurine concentrations of 0.05 and $0.5 \mathrm{mmol} / \mathrm{L}$ in MDCK kidney cells [50]. Thus, taurine may generally repress the Taut mRNA expression via negative feedback regulation. However, the TAUT protein levels were not affected, indicating that the TAUT protein amount may not be exclusively regulated at the transcriptional level. As observed by others, the TauT activity is tightly regulated and there might be a passive efflux via volume-sensitive anion channels [51,52]. Furthermore, it cannot be excluded that taurine may act via extracellular signaling or as taurine-conjugated metabolites such as $\mathrm{N}$-acyl taurine (NATs) or glutamyltaurine rather than in its free form [53].

The potential antioxidative properties of taurine in cultured $\mathrm{C} 2 \mathrm{C} 12$ cells were determined via TBARS and BODIPY assays. Under basal conditions, long-term taurine treatment $(48 \mathrm{~h})$ prevented the formation of lipid peroxidation products (TBARS) by approximately $60 \%$ compared to that of the control. Furthermore, the role of taurine in the protection of membrane PUFAs against oxidation was investigated using the fluorescent fatty acid analogue C11-BODIPY (581/591) as the LPO sensor. The impact of taurine on BODIPY oxidation was tested under basal conditions or after stimulation with low doses of $\mathrm{Fe}^{2+}$ and CumOOH. BODIPY oxidation was not different between untreated and taurine-supplemented cells under basal conditions. BODIPY oxidation was significantly increased upon treatment with CumOOH, an agent propagating LPO in cells; this effect was significantly counteracted by taurine. Because taurine is a water-soluble molecule, it seems unlikely that it accumulates in the lipid layer of membranes to directly inhibit the propagation of LPO. On the other hand, $\mathrm{CumOOH}$ is a semi-stable oxidizing agent that has to be "activated" by transition metals such as $\mathrm{Fe}^{2+}$ to form lipophilic cumoxyl radicals $\left(\mathrm{CumO}^{\bullet}\right)[54,55]$. Once it becomes a radical, CumO` attacks unsaturated fatty acids or other susceptible structures (e.g., BODIPY) within the lipid layer of biomembranes [8]. Thus, taurine supplementation may diminish the intracellular labile iron pool (LIP), and consequently, reduce the conversion of the semi-stable $\mathrm{CumOOH}$ to the more reactive $\mathrm{CumO}^{\bullet}$ radical.

In addition to the LPO biomarkers, cellular total glutathione (GSH) was reduced, and mRNA levels of genes encoding redox-sensitive antioxidative enzymes (Hmox1, Cat and Gclc) were significantly downregulated in response to taurine. Moreover, the catalase activity was reduced by approximately $40 \%$ due to the taurine treatment. These results support our hypothesis that taurine may act via 
suppression of oxygen radical formation (driven by free iron) rather than by upregulating defense and repair mechanisms induced by oxidatively damaged biomolecules. However, most of the assays applied in our study relate to unstressed cellular conditions. The presence of cellular stressors may also explain the contrasting results reported in the literature. Several other studies have indicated that taurine $[33,56,57]$ and its more potent derivative taurine chloramine $[31,58,59]$ enhance Hmox 1 expression through induction of the transcription factor nuclear factor erythroid 2-related factor 2 (Nrf2).

The impact of taurine on the protein expression of representative iron-associated proteins was determined via western blotting. Ferritin is the major iron storage protein in mammals and consists of 24 subunits and two isoforms, the light chain ferritin (FTL) and the heavy chain ferritin (FTH). FTH exerts ferroxidase activity and converts ferrous ions $\left(\mathrm{Fe}^{2+}\right)$ into the storable ferric $\left(\mathrm{Fe}^{3+}\right)$ form, while FTL aids in iron nucleation [60]. The arrangement of the ferritin subunit assembly is species- and tissue-specific [61]. Under the conditions investigated, taurine significantly increased the FTL protein levels more than two-fold but did not affect FTH protein levels. Interestingly, FTL-rich ferritin has been shown to accumulate more iron ions than FTH-rich ferritin [62]. Thus, the cellular storage capacity for iron may be augmented in taurine-supplemented cells, suggesting the prevention of accumulating excess labile iron. Moreover, the higher the proportion of protein-associated iron, the lower the LIP and, consequently, the extent of LPO [63,64]. Interestingly, Epsztejn et al. demonstrated that the reduction of LIP through ferritin was accompanied by a decrease in cellular glutathione content [63]. Furthermore, iron(II)glutathione was shown to be the dominant component of the labile iron pool [65]. Likewise, in our study, supplementation with taurine significantly reduced total glutathione levels in muscle cells.

Cellular LIP is sensed and regulated by iron responsive element-binding proteins (IRPs), which regulate ferritin and transferrin post-transcriptionally [66]. At low cellular labile iron levels, IRPs bind to iron-responsive elements (IREs) within the mRNA of the two ferritin isoforms and inhibit their translation. In contrast, binding of IRP to IRE of the Tfr mRNA inhibits its degradation and enhances transferrin translation and thus cellular iron uptake [67]. This may explain the higher Ftl and lower Tfr mRNA levels observed in our study in response to iron treatment (Figure 2B). Ftl and Fth were not different after taurine supplementation, while the protein concentration of FTL was significantly increased. It may be hypothesized that taurine supplementation modulated proteasomal FTL degradation in a regulatory mechanism that was independent of its transcript level, which has been described earlier [66,68]. Taken together, the regulation of IRP-induced modulation of LIP through taurine supplementation seems plausible and holds great potential for future studies.

Cellular iron exists beyond the free (LIP) in stored (ferritin) forms, which is crucial for the synthesis of iron-dependent proteins such as heme or iron-sulfur (Fe-S) cluster proteins. In our study, the levels of the heme proteins myoglobin and cytochrome $\mathrm{c}$ were significantly higher after taurine supplementation. This may further emphasize the shifting of cellular iron from labile forms to stored forms and protein association in response to taurine supplementation. In vivo, the majority of iron is bound to the heme protein hemoglobin in red blood cells, and there is evidence for a regulative role for taurine in this process. Oral iron treatment for iron-deficiency and anemia in women was more effective when taurine was co-supplemented [69], and circulating taurine was positively correlated with the amount of red blood cells in female endurance athletes [70].

Other mitochondrial proteins that require iron for assembly, including the Fe-S cluster proteins of the respiratory chain, were not affected by taurine. The mRNA level of Nupbl was increased, although it was the only gene affected among the tested genes that encoded mitochondrial Fe-S cluster proteins. To date, taurine has been suggested to affect the protein synthesis of the mitochondrially encoded subunits mt-ND5 and mt-ND6 [34]. It remains unclear whether taurine may modulate Fe-S protein cluster synthesis systematically and thereby modulate mitochondrial function. 


\section{Conclusions}

We provide evidence that taurine treatment of cells, which rely on exogenous taurine supply, reduces the extent of LPO, which we assume is caused by shifting of cellular iron from free to protein-associated forms. The involvement of labile iron pool sensing proteins and the role of taurine in mitochondrial Fe-S cluster protein synthesis and respiratory function warrant further investigation. It would be also interesting to validate the effect of taurine in cells and tissues with high iron stores and/or substantial iron metabolism, such as hepatocytes or osteoblasts. Moreover, tissue taurine levels, including skeletal muscle, are often diminished in aged versus young control animals [16-20]. Therefore, future studies should address the questions, whether dietary taurine supplementation affects redox- and iron-homeostasis during the aging process.

Supplementary Materials: The following are available online at http://www.mdpi.com/2076-3921/9/11/1071/s1, Figure S1: Western blots of three independent experiments showing the protein load of the membrane and the respective target bands of the (a) taurine transporter (TAUT) at $140 \mathrm{kDa}$, (b) ferritin light chain (FTL) at $19 \mathrm{kDa}$, (c) ferritin heavy chain (FTH) at $21 \mathrm{kDa},(\mathrm{d})$ myoglobin (MB) at $17 \mathrm{kDa}$, (e) Cytochrom C (CYTC) at $15 \mathrm{kDa}$ and (f) subunits of mitochondrial oxidative phosphorylation (OXPHOS) complexes CI (NADH dehydrogenese), CII (succinate dehydrogenase), CIII (ubiquinol-cytochrome c reductase), CIV (cytochrome c oxidase) and CV (ATP-Synthase) in response to control medium-(CON) and taurine-(TAUR) treatment.

Author Contributions: Conceptualization, G.R. and U.S.; methodology, U.S.; software, U.S.; validation, U.S. and K.L.; formal analysis, U.S.; investigation, U.S. and K.L.; resources, G.R.; data curation, U.S.; writing-original draft preparation, U.S. and G.R.; writing-review and editing, U.S., G.R., P.H. and K.L.; visualization, U.S.; supervision, P.H. and G.R.; project administration, G.R. All authors have read and agreed to the published version of the manuscript.

Funding: This research received no external funding.

Acknowledgments: We acknowledge financial support by the German Research Foundation (DFG) within the funding program “Open Access Publication".

Conflicts of Interest: The authors declare no conflict of interest.

\section{References}

1. Finch, C.A.; Deubelbeiss, K.; Cook, J.D.; Eschbach, J.W.; Harker, L.A.; Funk, D.D.; Marsaglia, G.; Hillman, R.S.; Slichter, S.; Adamson, J.W.; et al. Ferrokinetics in man. Medicine 1970, 49, 17-53. [CrossRef] [PubMed]

2. Lill, R. Function and biogenesis of iron-sulphur proteins. Nature 2009, 460, 831-838. [CrossRef] [PubMed]

3. Cozzi, A.; Corsi, B.; Levi, S.; Santambrogio, P.; Albertini, A.; Arosio, P. Overexpression of wild type and mutated human ferritin H-chain in HeLa cells: In vivo role of ferritin ferroxidase activity. J. Biol. Chem. 2000, 275, 25122-25129. [CrossRef] [PubMed]

4. Gao, J.; Richardson, D.R. The potential of iron chelators of the pyridoxal isonicotinoyl hydrazone class as effective antiproliferative agents, IV: The mechanisms involved in inhibiting cell-cycle progression. Blood 2001, 98, 842-850. [CrossRef] [PubMed]

5. Boniecki, M.T.; Freibert, S.A.; Mühlenhoff, U.; Lill, R.; Cygler, M. Structure and functional dynamics of the mitochondrial Fe/S cluster synthesis complex. Nat. Commun. 2017, 8, 1287. [CrossRef] [PubMed]

6. Lebigot, E.; Gaignard, P.; Dorboz, I.; Slama, A.; Rio, M.; de Lonlay, P.; Héron, B.; Sabourdy, F.; Boespflug-Tanguy, O.; Cardoso, A.; et al. Impact of mutations within the Fe-S cluster or the lipoic acid biosynthesis pathways on mitochondrial protein expression profiles in fibroblasts from patients. Mol. Genet. Metab. 2017, 122, 85-94. [CrossRef] [PubMed]

7. Breuer, W.; Epsztejn, S.; Ioav Cabantchik, Z. Dynamics of the cytosolic chelatable iron pool of K562 cells. FEBS Lett. 1996, 382, 304-308. [CrossRef]

8. Ayala, A.; Muñoz, M.F.; Argüelles, S. Lipid peroxidation: Production, metabolism, and signaling mechanisms of malondialdehyde and 4-hydroxy-2-nonenal. Oxid. Med. Cell. Longev. 2014, 2014, 360438. [CrossRef]

9. Stipanuk, M.H.; Ueki, I. Dealing with methionine/homocysteine sulfur: Cysteine metabolism to taurine and inorganic sulfur. J. Inherit. Metab. Dis. 2011, 34, 17-32. [CrossRef]

10. Seidel, U.; Huebbe, P.; Rimbach, G. Taurine: A Regulator of Cellular Redox Homeostasis and Skeletal Muscle Function. Mol. Nutr. Food Res. 2019, 63, e1800569. [CrossRef] 
11. Laidlaw, S.A.; Grosvenor, M.; Kopple, J.D. The taurine content of common foodstuffs. JPEN J. Parenter. Enteral Nutr. 1990, 14, 183-188. [CrossRef]

12. Huxtable, R.J. Physiological actions of taurine. Physiol. Rev. 1992, 72, 101-163. [CrossRef] [PubMed]

13. Ripps, H.; Shen, W. Review: Taurine: A “very essential" amino acid. Mol. Vis. 2012, 18, 2673-2686.

14. Chesney, R.W. Taurine: Its biological role and clinical implications. Adv. Pediatr. 1985, 32, 1-42. [PubMed]

15. Oliveira, M.W.S.; Minotto, J.B.; de Oliveira, M.R.; Zanotto-Filho, A.; Behr, G.A.; Rocha, R.F.; Moreira, J.C.F.; Klamt, F. Scavenging and antioxidant potential of physiological taurine concentrations against different reactive oxygen/nitrogen species. Pharmacological. Reports 2010, 62, 185-193. [CrossRef]

16. Wang, Y.; Grenell, A.; Zhong, F.; Yam, M.; Hauer, A.; Gregor, E.; Zhu, S.; Lohner, D.; Zhu, J.; Du, J. Metabolic signature of the aging eye in mice. Neurobiol. Aging 2018, 71, 223-233. [CrossRef]

17. Massie, H.R.; Williams, T.R.; DeWolfe, L.K. Changes in taurine in aging fruit flies and mice. Exp. Gerontol. 1989, 24, 57-65. [CrossRef]

18. Dawson, R.; Pelleymounter, M.A.; Cullen, M.J.; Gollub, M.; Liu, S. An age-related decline in striatal taurine is correlated with a loss of dopaminergic markers. Brain Res. Bull. 1999, 48, 319-324. [CrossRef]

19. Eppler, B.; Dawson, R. Dietary taurine manipulations in aged male Fischer 344 rat tissue: Taurine concentration, taurine biosynthesis, and oxidative markers. Biochem. Pharmacol. 2001, 62, 29-39. [CrossRef]

20. Pierno, S.; de Luca, A.; Camerino, C.; Huxtable, R.J.; Camerino, D.C. Chronic administration of taurine to aged rats improves the electrical and contractile properties of skeletal muscle fibers. J. Pharmacol. Exp. Ther. 1998, 286, 1183-1190.

21. Tallon, M.J.; Harris, R.C.; Maffulli, N.; Tarnopolsky, M.A. Carnosine, taurine and enzyme activities of human skeletal muscle fibres from elderly subjects with osteoarthritis and young moderately active subjects. Biogerontology 2007, 8, 129-137. [CrossRef] [PubMed]

22. Cornet, M.; Bousset, J. Free amino acids and dipeptides in porcine muscles: Differences between 'red' and 'white' muscles. Meat Sci. 1999, 51, 215-219. [CrossRef]

23. Dunnett, M.; Harris, R.C.; Sewell, D.A. Taurine content and distribution in equine skeletal muscle. Scand. J. Clin. Lab. Invest. 1992, 52, 725-730. [CrossRef]

24. Iwata, H.; Obara, T.; Kim, B.K.; Baba, A. Regulation of taurine transport in rat skeletal muscle. J. Neurochem. 1986, 47, 158-163. [CrossRef]

25. Matsuzaki, Y.; Miyazaki, T.; Miyakawa, S.; Bouscarel, B.; Ikegami, T.; Tanaka, N. Decreased taurine concentration in skeletal muscles after exercise for various durations. Med. Sci. Sports Exerc. 2002, 34, 793-797. [CrossRef] [PubMed]

26. Stuerenburg, H.J.; Stangneth, B.; Schoser, B.G.H. Age related profiles of free amino acids in human skeletal muscle. Neuro Endocrinol. Lett. 2006, 27, 133-136.

27. Terrill, J.R.; Grounds, M.D.; Arthur, P.G. Taurine deficiency, synthesis and transport in the mdx mouse model for Duchenne Muscular Dystrophy. Int. J. Biochem. Cell Biol. 2015, 66, 141-148. [CrossRef]

28. Hofer, T.; Marzetti, E.; Xu, J.; Seo, A.Y.; Gulec, S.; Knutson, M.D.; Leeuwenburgh, C.; Dupont-Versteegden, E.E. Increased iron content and RNA oxidative damage in skeletal muscle with aging and disuse atrophy. Exp. Gerontol. 2008, 43, 563-570. [CrossRef]

29. DeRuisseau, K.C.; Park, Y.-M.; DeRuisseau, L.R.; Cowley, P.M.; Fazen, C.H.; Doyle, R.P. Aging-related changes in the iron status of skeletal muscle. Exp. Gerontol. 2013, 48, 1294-1302. [CrossRef]

30. Cheong, S.H.; Moon, S.H.; Lee, S.J.; Kim, S.H.; Chang, K.J. Antioxidant and DNA protection effects of taurine by electron spin resonance spectroscopy. Adv. Exp. Med. Biol. 2013, 776, 167-177. [CrossRef]

31. Piao, S.; Cha, Y.-N.; Kim, C. Taurine chloramine protects RAW 264.7 macrophages against hydrogen peroxide-induced apoptosis by increasing antioxidants. J. Clin. Biochem. Nutr. 2011, 49, 50-56. [CrossRef]

32. Kang, I.S.; Kim, C. Taurine chloramine administered in vivo increases NRF2-regulated antioxidant enzyme expression in murine peritoneal macrophages. Adv. Exp. Med. Biol. 2013, 775, 259-267. [CrossRef] [PubMed]

33. Yang, W.; Huang, J.; Xiao, B.; Liu, Y.; Zhu, Y.; Wang, F.; Sun, S. Taurine Protects Mouse Spermatocytes from Ionizing Radiation-Induced Damage Through Activation of Nrf2/HO-1 Signaling. Cell. Physiol. Biochem. 2017, 44, 1629-1639. [CrossRef]

34. Jong, C.J.; Azuma, J.; Schaffer, S. Mechanism underlying the antioxidant activity of taurine: Prevention of mitochondrial oxidant production. Amino Acids 2012, 42, 2223-2232. [CrossRef] 
35. Oudit, G.Y.; Trivieri, M.G.; Khaper, N.; Husain, T.; Wilson, G.J.; Liu, P.; Sole, M.J.; Backx, P.H. Taurine supplementation reduces oxidative stress and improves cardiovascular function in an iron-overload murine model. Circulation 2004, 109, 1877-1885. [CrossRef]

36. Zhang, Z.; Liu, D.; Yi, B.; Liao, Z.; Tang, L.; Yin, D.; He, M. Taurine supplementation reduces oxidative stress and protects the liver in an iron-overload murine model. Mol. Med. Rep. 2014, 10, 2255-2262. [CrossRef]

37. Gabr, S.A.; Gabr, N.S.; Elsaed, W.M. Protective Activity of Taurine and Molecular Fibrogenesis in Iron Overloaded Hepatic Tissues. Int. J. Pharmacol. 2019, 15, 418-427. [CrossRef]

38. Petrova, Y.S.; Neudachina, L.K. Potentiometric study of complexation between taurine and metal ions. Russ. J. Inorg. Chem. 2013, 58, 617-620. [CrossRef]

39. Borenfreund, E.; Puerner, J.A. Toxicity determined in vitro by morphological alterations and neutral red absorption. Toxicol. Lett. 1985, 24, 119-124. [CrossRef]

40. Kei, S. Serum lipid peroxide in cerebrovascular disorders determined by a new colorimetric method. Clin. Chim. Acta 1978, 90, 37-43. [CrossRef]

41. Vandeputte, C.; Guizon, I.; Genestie-Denis, I.; Vannier, B.; Lorenzon, G. A microtiter plate assay for total glutathione and glutathione disulfide contents in cultured/isolated cells: Performance study of a new miniaturized protocol. Cell Biol. Toxicol. 1994, 10, 415-421. [CrossRef] [PubMed]

42. Rahman, I.; Kode, A.; Biswas, S.K. Assay for quantitative determination of glutathione and glutathione disulfide levels using enzymatic recycling method. Nat. Protoc. 2006, 1, 3159-3165. [CrossRef]

43. Johansson, L.H.; Håkan Borg, L.A. A spectrophotometric method for determination of catalase activity in small tissue samples. Anal. Biochem. 1988, 174, 331-336. [CrossRef]

44. Ito, T.; Yoshikawa, N.; Inui, T.; Miyazaki, N.; Schaffer, S.W.; Azuma, J. Tissue depletion of taurine accelerates skeletal muscle senescence and leads to early death in mice. PLoS ONE 2014, 9, e107409. [CrossRef] [PubMed]

45. Ito, T.; Yoshikawa, N.; Schaffer, S.W.; Azuma, J. Tissue taurine depletion alters metabolic response to exercise and reduces running capacity in mice. J. Amino Acids 2014, 2014, 964680. [CrossRef]

46. Ito, T.; Kimura, Y.; Uozumi, Y.; Takai, M.; Muraoka, S.; Matsuda, T.; Ueki, K.; Yoshiyama, M.; Ikawa, M.; Okabe, M.; et al. Taurine depletion caused by knocking out the taurine transporter gene leads to cardiomyopathy with cardiac atrophy. J. Mol. Cell. Cardiol. 2008, 44, 927-937. [CrossRef] [PubMed]

47. Warskulat, U.; Flögel, U.; Jacoby, C.; Hartwig, H.-G.; Thewissen, M.; Merx, M.W.; Molojavyi, A.; Heller-Stilb, B.; Schrader, J.; Häussinger, D. Taurine transporter knockout depletes muscle taurine levels and results in severe skeletal muscle impairment but leaves cardiac function uncompromised. FASEB J. 2004, 18, 577-579. [CrossRef]

48. Heller-Stilb, B.; van Roeyen, C.; Rascher, K.; Hartwig, H.-G.; Huth, A.; Seeliger, M.W.; Warskulat, U.; Häussinger, D. Disruption of the taurine transporter gene (taut) leads to retinal degeneration in mice. FASEB J. 2002, 16, 231-233. [CrossRef]

49. Froger, N.; Moutsimilli, L.; Cadetti, L.; Jammoul, F.; Wang, Q.-P.; Fan, Y.; Gaucher, D.; Rosolen, S.G.; Neveux, N.; Cynober, L.; et al. Taurine: The comeback of a neutraceutical in the prevention of retinal degenerations. Prog. Retin. Eye Res. 2014, 41, 44-63. [CrossRef]

50. Han, X.; Budreau, A.M.; Chesney, R.W. Adaptive regulation of MDCK cell taurine transporter (pNCT) mRNA: Transcription of pNCT gene is regulated by external taurine concentration. Biochim. Biophys. Acta Gen Struct. Expr. 1997, 1351, 296-304. [CrossRef]

51. Voss, J.W.; Pedersen, S.F.; Christensen, S.T.; Lambert, I.H. Regulation of the expression and subcellular localization of the taurine transporter TauT in mouse NIH3T3 fibroblasts. Eur. J. Biochem. 2004, 271, 4646-4658. [CrossRef] [PubMed]

52. Hansen, D.B.; Guerra, B.; Jacobsen, J.H.; Lambert, I.H. Regulation of taurine homeostasis by protein kinase CK2 in mouse fibroblasts. Amino Acids 2011, 40, 1091-1106. [CrossRef] [PubMed]

53. Ito, T.; Murakami, S.; Schaffer, S.W. Taurine-Conjugated Metabolites in Hearts. Adv. Exp. Med. Biol. 2019, 1155, 523-529. [CrossRef] [PubMed]

54. Minotti, G.; Aust, S.D. Redox cycling of iron and lipid peroxidation. Lipids 1992, 27, 219-226. [CrossRef]

55. Tadolini, B.; Cabrini, L.; Menna, C.; Pinna, G.G.; Hakim, G. Iron (III) stimulation of lipid hydroperoxide-dependent lipid peroxidation. Free Radic. Res. 1997, 27, 563-576. [CrossRef]

56. Park, S.Y.; Ahn, C.-B.; Chang, K.J.; Kim, S.H.; Lee, W.; Um, J.H.; Han, E.J.; Jeon, Y.-J.; Cheong, S.H.; Ahn, G. Hepatoprotective Effects of Xylose-Taurine Reduced Against Hydrogen Peroxide-Induced Oxidative Stress in Cultured Hepatocytes. Adv. Exp. Med. Biol. 2017, 975 Pt 1, 621-631. [CrossRef] 
57. Sun, Q.; Jia, N.; Yang, J.; Chen, G. Nrf2 Signaling Pathway Mediates the Antioxidative Effects of Taurine Against Corticosterone-Induced Cell Death in HUMAN SK-N-SH Cells. Neurochem. Res. 2018, 43, 276-286. [CrossRef]

58. Sun Jang, J.; Piao, S.; Cha, Y.-N.; Kim, C. Taurine Chloramine Activates Nrf2, Increases HO-1 Expression and Protects Cells from Death Caused by Hydrogen Peroxide. J. Clin. Biochem. Nutr. 2009, 45, 37-43. [CrossRef]

59. Cheong, S.H.; Lee, D.-S. Taurine Chloramine Prevents Neuronal HT22 Cell Damage Through Nrf2-Related Heme Oxygenase-1. Adv. Exp. Med. Biol. 2017, 975 Pt 1, 145-157. [CrossRef]

60. Harrison, P.M.; Arosio, P. The ferritins: Molecular properties, iron storage function and cellular regulation. Biochim. Biophys. Acta Bioenerg. 1996, 1275, 161-203. [CrossRef]

61. Arosio, P.; Yokota, M.; Drysdale, J.W. Structural and Immunological Relationships of Isoferritins in Normal and Malignant Cells. Cancer Res. 1976, 36, 1735-1739.

62. Levi, S.; Santambrogio, P.; Cozzi, A.; Rovida, E.; Corsi, B.; Tamborini, E.; Spada, S.; Albertini, A.; Arosio, P. The role of the L-chain in ferritin iron incorporation. Studies of homo and heteropolymers. J. Mol. Biol. 1994, 238, 649-654. [CrossRef] [PubMed]

63. Epsztejn, S.; Glickstein, H.; Picard, V.; Slotki, I.N.; Breuer, W.; Beaumont, C.; Cabantchik, Z.I. H-ferritin subunit overexpression in erythroid cells reduces the oxidative stress response and induces multidrug resistance properties. Blood 1999, 94, 3593-3603. [CrossRef]

64. Orino, K.; Lehman, L.; Tsuji, Y.; Ayaki, H.; Torti, S.V.; Torti, F.M. Ferritin and the response to oxidative stress. Biochem. J. 2001, 357, 241-247. [CrossRef] [PubMed]

65. Hider, R.C.; Kong, X.L. Glutathione: A key component of the cytoplasmic labile iron pool. Biometals 2011, 24, 1179-1187. [CrossRef]

66. Sammarco, M.C.; Ditch, S.; Banerjee, A.; Grabczyk, E. Ferritin L and H subunits are differentially regulated on a post-transcriptional level. J. Biol. Chem. 2008, 283, 4578-4587. [CrossRef]

67. Wang, J.; Pantopoulos, K. Regulation of cellular iron metabolism. Biochem. J. 2011, 434, 365-381. [CrossRef]

68. Gryzik, M.; Srivastava, A.; Longhi, G.; Bertuzzi, M.; Gianoncelli, A.; Carmona, F.; Poli, M.; Arosio, P. Expression and characterization of the ferritin binding domain of Nuclear Receptor Coactivator-4 (NCOA4). Biochim. Biophys. Acta Gen. Subj. 2017, 1861, 2710-2716. [CrossRef]

69. Sirdah, M.M.; El-Agouza, I.M.A.; Abu Shahla, A.N.K. Possible ameliorative effect of taurine in the treatment of iron-deficiency anaemia in female university students of Gaza, Palestine. Eur. J. Haematol. 2002, 69, 236-242. [CrossRef]

70. Momma, R.; Kumagai, H.; Oshiden, M.; Iemitsu, M.; Maeda, S. Relationship between anemia and circulating levels of amino acids in female endurance athletes. Jpn. J. Phys. Fit. Sports Med. 2017, 66, 391-397. [CrossRef]

Publisher's Note: MDPI stays neutral with regard to jurisdictional claims in published maps and institutional affiliations.

(C) 2020 by the authors. Licensee MDPI, Basel, Switzerland. This article is an open access article distributed under the terms and conditions of the Creative Commons Attribution (CC BY) license (http://creativecommons.org/licenses/by/4.0/). 